Buletin Psikologi, Volume 29, Number 1, 2021: (page 116 - 129)

ISSN 0854-7106 (print) I ISSN 2528-5858 (Online)

https://jurnal.ugm.ac.id/buletinpsikologi

DOI: $10.22146 /$ buletinpsikologi.56729

\title{
The Dynamic of Intimacy in Prostitution
}

\author{
I Kadek Wahyu Pujhana1, Made Diah Lestari ${ }^{1,2}$ \\ ${ }^{1}$ Department of Psychology, Faculty of Medicine, Universitas Udayana \\ ${ }^{2}$ School of Psychology, College of Humanities and Social Sciences, Massey University
}

Submitted 8 June 2020 Accepted 28 September 2020 Published 28 June 2021

\begin{abstract}
The study of prostitution in Indonesia is dominated by economic, legal, social and health studies. Psychological studies related to the dynamics of intimacy are still limited and mostly conducted in the context of sexual and reproductive health, namely the use of condoms. Intimacy in this article refers to closeness, attachment, and comfort that are psychologically important for prostitutes to manage in order to maintain a personal relationship with clients. The purpose of this article is to describe intimacy in the world of prostitution. Through literature studies and by limiting the study on female prostitutes, this article discusses the definition of prostitution, its history in Indonesia, the role of intimacy in prostitution, the boundaries of intimate relationships, and the link between intimacy and condom use. Two discourses, intimacy as part of sexual relations and intimacy as a form of embeddedness in an economic context are used to understand the boundary line between intimacy as a commercial relationship and intimacy as a non-commercial relationship. This article is expected to contribute to the psychological, legal, and health aspects of prostitution.

Keywords: intimacy; prostitution; prostitute
\end{abstract}

\section{Introduction}

Prostitution is understood as a commercial exchange. This draws on the definitions of prostitution developed by many experts (Hidayati \& Suhartini, 2013; Jeffreys, 2008; Koentjoro, 2004; Nazemi, 2011; Wahyuni, 2014). Most of these definitions refer to prostitution as an exchange of (sexual) services for monetary compensation (Hidayati \& Suhartini, 2013; Jeffreys, 2008; Khumaerah, 2017; Koentjoro, 2004; Nazemi, 2011; Rusyidi \& Nurwati, 2018; Wahyuni, 2014). It is not surprising then that the economic aspect of prostitution has become the focus of attention rather than the affective aspect of it, in this instance the intimacy between prostitutes and their clients. Jeffreys (2008) stated that the ability to manipulate emotions in serving clients is a hallmark of prostitution. With emotional manipulation defining it, the intimacy aspect of a sexual relationship is implicitly considered unimportant in the context of prostitution. On the other hand, prostitutes are individuals who also have an affective aspect in addition to cognitive and motoric aspects. The thinking that disregards the intimacy aspect, emphasizes the commercial values, and refers more widely to women has become the starting point of feminism' critique for prostitution (Jeffreys, 2008). 
To date, studies related to intimacy both in the western and Indonesia have put the focus of the role of intimacy more on condom use in the context of sexual and reproductive health (Bailey \& Figueroa, 2018; Barker et al., 2018; Deering et al., 2011; Destrianti \& Harnani, 2018; Matahari, 2012; Warr \& Pyett, 1999). On the other hand, there are not many studies that give an understanding of intimacy in particular and also in the context of Indonesia, even though the practice of prostitution in Indonesia has existed since the kingdom era and much of it involves the role of intimacy and emotions, rather than merely an economic transaction (Basuki et al., 2002; Koentjoro, 2004; Ridlwan, 2015; Rivai, 2012; Rizal, 2017). It could be that this kind of study is still considered a taboo by many researchers.

Through study of literature this article discusses the dynamics of intimacy perceived by prostitutes. This article focuses on the context of the study of intimacy that is formed between female prostitutes and their clients in general, using the theoretical approach of intimacy and social embeddedness. Male prostitutes are excluded from this article due to the assumption that women and men may have different dynamics, and therefore require separate studies. The discussion includes the definition and history of prostitution in Indonesia to provide an overview in relation to the cultural and historical context. It is expected that this article will contribute to further research on intimacy by presenting a new perspective on prostitution in Indonesia.

\section{Definition of Prostitution}

\section{Discussion}

Prostitute, hooker, sex worker, PSK (Pekerja Seks Komersial, commercial sex worker), WTS (Wanita Tuna Susila, woman devoid of morality) are some of the terms that are widely known in society that refer to someone who delivers sexual services in exchange for monetary compensation. In a narrow sense, a prostitute is defined as someone who is female who offers her services as a slave and is paid by men to provide sexual satisfaction (Jeffreys, 2008; Koentjoro, 2004; Nazemi, 2011). A prostitute also means a woman who works to sell herself to men who need sexual satisfaction, and the woman gets a sum of money in return, and it is all done outside of marriage (Wahyuni, 2014). This 'outlet' for men's sexual desires is then identified as a woman who may sleep with more than one man in the practice of prostitution (Hidayati \& Suhartini, 2013).

According to Koentjoro (2004), the term 'prostitute' refers to the "person" who carries out an act of prostitution, while the term 'prostitution' refers to the "act" carried out by the prostitute. Prostitution is the selling of sexual services, such as sexual intercourse, to get money, and involves various parties such as the client, the pimp, and the intermediary (Khumaerah, 2017; Rusyidi \& Nurwati, 2018). Transaction, infidelity, and emotional indifference are the three main components of prostitution (Koentjoro, 2004). It can be concluded that most of the definitions of prostitution focus on the commercial aspect, i.e. exchange for money, and also focus on women as prostitutes and men as clients.

\section{The History of Prostitution in Indonesia}

The history of prostitution in Indonesia began with the terms permaisuri (empress consort, as the legitimate wife) and selir (a concubine, as an illegitimate wife) during the Majapahit empire (Koentjoro, 2004; Ridlwan, 2015). The existence of concubines was believed to be a 
symbol of power for an empire, because these concubines could act as spies to protect the empire's security. Wonogiri and Wonosari were labelled as "pleasure" zones for prostitution, and they saw an increase in the demand for sex services during the colonial period (Ridlwan, 2015). Furthermore, reforms in agrarian law and the economy of colonized countries began to be implemented in 1970, giving rise to expansion of plantations and the oil refining industry, which led to a rising number of ladies of the night in plantation areas, factories, and workers' locations until 1990 (Koentjoro, 2004).

Prostitution in Indonesia has now become further perpetuated, because there are various parties that enable this practice. The high level of demand causes intermediaries (pimps, ex-prostitutes) to recruit a large number of women to keep up the supply of prostitutes. Examples include the establishment of a plantation company in Jember in 1974 which resulted in the emergence of prostitution places in development areas; the boredom felt by railway construction workers from Batavia, Bogor, Cianjur, Bandung, Cilacap, Yogyakarta, and Surabaya which prompted a lot of prostitutes to flock in Pasar Kembang in Yogyakarta; and the phenomenon of contract marriage between Arab tourists and local residents in the area of Cisarua, Bogor (Artosa, 2018; Jailani \& Badriyanto, 2014; Wahab et al., 2018). Today, the practice of prostitution in Indonesia has developed in new places such as karaoke, nightclubs, and discos, with some specially offered to the elite (Koentjoro, 2004).

Looking at the stereotypes of prostitution in Indonesia, needless to say it is considered an activity that violates social norms, is not recognized by the majority of faiths and religions, and goes against the legal viewpoints in Indonesia, namely the values of Pancasila and the Indonesian laws and regulations. The Indonesian government has actually put in place criminal sanctions for acts related to prostitution, as regulated in Article 296 of the Indonesian Criminal Code, Article 506 of the Indonesian Criminal Code, Law no. 21 of 2007 on the Eradication of the Criminal Act of Trafficking in Persons (TIP Law), Law no. 44 of 2008 on Pornography (Pornography Law), Law no. 35 of 2014 on Child Protection (Child Protection Law), and Law no. 19 of 2016 on Electronic Information and Transactions (EIT Law) (Kusumawati \& Rochaeti, 2019). However, the practice of prostitution will continue to exist as long as there is high demand from consumers. This can be seen from the large distribution of the supply of prostitutes in various locations and the various categories of prostitutes in Indonesia, namely (1) based on the structure: lower-class, middle-class, upper-class, and high-class prostitutes; (2) based on the structure and operational system: street prostitutes, bar/café prostitutes, and brothel prostitutes; (3) based on the type: the categories are differentiated based on their sex, rates, age, professionalism, work methods, requirements, and education (Henderina, 2012; Koentjoro, 2004).

\section{Intimacy and Prostitution}

In 2014, a case of murder of a prostitute in the area of Sanur, Denpasar became the focus of public attention. The murder of the prostitute by the initial A was done by her client at one location on Danau Tempe St., Sanur, Denpasar because the client felt that he had not been served well by A. He was a regular client who had booked the service of the prostitute A for 4 times. The situation turned a different direction at their last meeting, when A only gave the client a short service, where she gave him a kiss briefly and then 
rushed to finish the service. Not happy with the short service given, in September 2014 the client killed A when she was done serving him (Liputan6.com, 2014).

The above case shows that comfort and closeness in the form of intimacy from a client can be established in the world of prostitution, which can be seen from the client's consistent choice of booking the prostitute A for 4 times. On the contrary, it was the prostitute A who was reluctant to develop the intimacy in maintaining relationships with clients. In relation to the discussion of intimacy in the next section, this could be because a prostitute's ability to manipulate her emotions such as displaying or hiding emotions while working is one important component that serves as the main support for a prostitute's professionalism apart from physical and sexual abilities. When making direct contact with clients, prostitutes are required to pay attention and show intense emotions to them. On the other hand, at the same time they must be careful in managing emotional situations when interacting with clients (Carbonero \& Gómez Garrido, 2018). These emotional transitions sometimes cause prostitutes to constantly be in a state of having fake and intense feelings as they have to carefully manage their inner emotions and expressions as part of a professional performance (Carbonero \& Gómez Garrido, 2018). This psychological ability is often not directly visible, but its existence will certainly affect a relationship, especially in commercial sex.

Psychologically, in a personal relationship, comfort and attachment are formed through intimacy. Intimacy is a feeling of mutual trust which ultimately leads to deeper closeness in a romantic relationship (Sumter et al., 2013). Intimacy also serves as a symbol of love that is greater than oral sex, and this feeling can mutually benefit each party to a relationship (Vannier \& Byers, 2013). Through intimacy, the relationship is shown to be a close personal relationship, because in it there is also love, tenderness, trust, and openness to one's partner (Czyżowska et al., 2019). It can be said that intimacy is a feeling of mutual trust that makes a relationship closer, deeper, and tighter, which will certainly benefit the relationship and make it more romantic. This is consistent with what Reis (1990) asserted, that intimacy is a feeling that naturally occurs in a relationship, and if there is no intimacy in the interactions in a relationship, it can be predicted that the relationship will experience psychological barriers.

As opposed to the definition of intimacy in a relationship, Järvinen and Henriksen (2018) discussed the issue of intimacy and control in prostitution in Denmark, and argued that the boundary between the two is still ambiguous. The Danish prostitutes in the study were described as having complete control over choosing when to perform a commercial relationship with or without intimacy and as being able to distinguish the conditions of being "used" and "paid" in the activity. In addition, descriptions of intimate encounters in prostitution vary. One of them concerns the boundaries between commercial and noncommercial sexual relations of the prostitutes in Denmark, which in fact are almost nonexistent. They found it difficult to tell apart intimate feelings in commercial or noncommercial sex, for real or for pretend, and in public or private domain.

It can be said that prostitutes experience ambiguity in overcoming emotional boundaries in working as part of the sex services (Järvinen \& Henriksen, 2018). It can be concluded here that the concept of intimacy experienced by prostitutes actually lies mostly in the level of a relationship between clients and service providers in a business or economic context, which in this case is termed as social embeddedness (Granovetter, 
1985). Social embeddedness explains that in an economic relationship, personal relation and closeness from each actor are needed to create valuable services (Granovetter, 1985).

It becomes interesting when the study of prostitution is discussed in two main discourses, namely the discourse of intimacy as part of sexual relations and the discourse of intimacy as a form of social embeddedness in an economic context. The discussion related to the two discourses will be divided into a discussion on the role and limits of intimacy, and a study of intimacy and condom use. The main question that should be kept in mind when reading this article is whether it is true that prostitution has completely transformed an affective sexual relationship into a commodity in the economic world that emphasizes on emotional absence? Or is it the other way around? Or is it more complex than previously imagined?

\section{The Role - Between Affection and Economic Goals}

By its nature, prostitution requires direct contact, most of which will be physical contact, which does not rule out the possibility of involving direct emotional contact with clients. Research has found that emotions play an important role in sexual services. Intimacy can be constructed by how a person makes first impression, build closeness with others to foster a sense of affection, warmth, and caring which can lead to satisfaction in sexual relationships (Cessia \& Lestari, 2017). Intimacy in prostitution in Indonesia can be seen when a prostitute is able to keep her regular client and make him engage in sexual relations with her multiple times, and feels jealous when her regular client comes out of the room of another prostitute (Basuki et al., 2002). This indicates that intimacy can be used as a weapon to retain and attach clients so that they continue their relations with a prostitute.

As for other prostitutes, a number of prostitutes in Spain hoped to be able to enjoy the intimacy of sexual relations and turn themselves into someone who could naturally enjoy sexual relations (Carbonero \& Gómez Garrido, 2018). If they did not enjoy the sexual relations, clients would be disappointed because they would think that the prostitute was lying and making sexual relations a mere mechanical activity (Carbonero \& Gómez Garrido, 2018). Seeing this, it becomes important that a sexual relation is made based on sexual desire, rather than because of an obligation, but instead because of wanting to have sex. Self-disclosure of significant experiences in life such as past events, hopes, fears, or desires is a key element in creating intimacy (Carbonero \& Gómez Garrido, 2018). The question is, to what extent is a prostitute able to disclose important aspects of her life as a step to develop intimacy with a client who is a "stranger"? On the other hand, this psychological intimacy is an important component of a satisfying sexual relationship.

One indicator of intimacy in prostitution is kissing, and it is not uncommon for a prostitute to use kissing as a "pretend" tool to show intimacy and interest to a client. Hugging is also a sexual marker that reflects the themes of love, intimacy, closeness, and comfort in an interaction (van Anders et al., 2013). In other words, kisses and hugs can be markers of intimacy in commercial sex. For prostitutes, kissing is the most important strategy in the service of prostitution (Carbonero \& Gómez Garrido, 2018). In line with research in the western world, a study conducted by Rivai (2012) on prostitutes who used online applications in Yogyakarta showed that four out of eight respondents used kissing as a strategy to retain clients by listing the service in their tariff. One respondent admitted 
that she was never half-hearted when serving her clients, that her service included sexual service complete with kissing (Rivai, 2012). Later, Rizal (2017) supported this finding by confirming that prostitutes in Tondo Kiri, Central Sulawesi gave kisses to clients, either in the form of direct kisses or just long-distance kisses as a strategy for them to get clients. This was done so that potential clients would feel attracted and so that the prostitute would be considered the right person to be hired (Rizal, 2017).

On the other hand, intimacy is used as a weapon in the world of prostitution to achieve the goal of the prostitute. A study by Vuolajärvi's (2019) found that prostitutes in Europe, who were mostly immigrants, began to exploit intimacy with clients to obtain a permanent residency in a country by getting married to the client or being given an opportunity to work in a company by the client. These two methods were considered effective and successful in providing a way for immigrants to secure the legality of permanent residence in the destination country. However, this only served a short-term purpose. Some prostitutes in this study mentioned that after they achieved their goal of having a legal residence permit, their relationships with their clients began to gradually become cold, and filled with anger and jealousy, causing them to fail to marry even though the immigrant prostitutes had achieved their goal of living in Europe (Vuolajärvi, 2019).

Previous research revealed that many would spontaneously choose to engage in prostitution to overcome their financial difficulties (Bailey \& Figueroa, 2018). The easiest way is to use the only asset they have, which is their body parts. Women who engage in prostitution more frequently report that they are selling themselves to earn money to purchase illicit drugs, and also due to lack of alternative income (Järvinen \& Henriksen, 2018). This brought Weinberg in Järvinen and Henriksen (2018) to conclude that women seem to be more likely 'trapped' in prostitution than men.

This 'trapped' situation is also mentioned in Bailey and Figueroa's research (2018) which states that most female prostitutes enter prostitution due to poor socio-economic conditions, dropping out of school because of early pregnancy, poverty, and drug abuse. The prostitutes in Bailey and Figueroa's research (2018) also said that sex work presented them with a choice to survive and live a decent life, and one way to do it is by retaining regular clients through offers of intimacy, even though they knew that this would increase their risk of contracting HIV/STIs (Bailey \& Figueroa, 2018). Social embeddedness in this case appears to be at the heart of economic relations, which results in the prostitute being in between intimacy and social embeddedness.

Apart from the role of intimacy in prostitution in western countries, in Indonesia, intimacy actually has a very crucial role, if examined from the perspective of the history of prostitution in Indonesia. Prostitution is nothing new; during the royal times, the existence of concubines was actually a different form of prostitution (Hull et al., 1997). To date, there are eleven regions in Indonesia that are the main suppliers of prostitutes, as part of the legacy of the practice of prostitution during the feudalism era (Hull et al., 1997). This was the case during the Dutch and Japanese colonial times, and it continued up until the Indonesia's independence. There are many films and books inspired by the stories of intimacy between kings and concubines, indigenous women and colonial soldiers either as the background or the main story, one of which is the book titled Perempuan-Perempuan Perkasa di Jawa Abad XVIII-XIX (Strong Women in Java in the 18th19th Centuries) (Carey \& Houben, 2016). 


\section{The Boundaries - Being in Ambiguity}

This part will discuss how intimacy is perceived by prostitutes and the strategies used to overcome ambiguity. However, this section will discuss more about studies conducted outside the Indonesian context because previous research is still very limited. Any discussion on the boundaries of intimacy will encourage us to think about what if the same concept is applied in Indonesia.

The definition of intimacy in prostitution varies greatly. Intimacy is also distinguished between intimacy in commercial sexual relations and that in noncommercial sexual relations. Being a prostitute in Denmark is considered a "social reward" because only by offering services to accommodate and satisfy the sexual desires of the client will the prostitute be rewarded for her services with monetary compensation (Järvinen \& Henriksen, 2018). Connecting it to the history of prostitution, the legal aspect, the economic aspect, and social acceptance in Indonesia, is it possible for prostitution to be considered a social reward? Can this concept foster a sense of pride of one's identity as a prostitute, or on the contrary, will it become a concealed identity when a prostitute develops intimacy?

As professionally intimacy in commercial and non-commercial contexts can be distinguished, the following paragraphs help us to understand how prostitutes draw clear boundaries and make clear 'warning' signs when crossing the lines. Some of the findings can be used as indicators for developing cross-cultural research in understanding intimacy.

The first indicator is physical closeness, which consists of avoiding kissing and avoiding being attracted to clients. In Carbonero and Gómez Garrido's research (2018) on street prostitutes in Madrid, Barcelona, Palma, and Spain, it is explained that there are clear boundaries as when to feel intimate in a commercial relationship, and when to feel intimate in a non-commercial relationship. There was a difference because the street prostitutes in this study would not kiss their clients because they were not their boyfriends. In addition, the street prostitutes also argue that kissing involves a romantic imagination which is clearly different in the context of a commercial relationship compared to that in a personal or non-commercial relationship. For the street prostitutes, intimacy is only meant for personal relationships such as with family members and partners.

On the other hand, ambiguous boundaries begin when the street prostitutes feel attracted to their clients, especially clients who are young and have an attractive appearance. However, actually they avoid being attracted to their clients, because if they do, they may fail to maintain their ability to control their desires and pleasures as a form of self-protection and emotional control. Hence, for street prostitutes in Spain, sex as work would be set separately from sex as pleasure. In other words, intimacy and social embeddedness are clearly distinguished.

The next indicator is intimacy as trust and commitment to the client. Beetles and Harris (2010) found that in a commercial relationship, intimacy can actually be used as a tool in building relationships. The study, which was conducted in the UK, mentioned that some respondents would return to the same woman for sexual services. Sex clients in the study also confirmed that intimacy was used to make commercial relationships more developed between clients and service providers, in this case prostitutes. Clearly in a 
commercial context, the key components of the relational approach, namely trust and commitment, must play a role in facilitating business transactions. Social bonds are also important but the level of an intimate relationship present in such bonds goes far beyond the intended one and leaves no boundaries. In other words, without "warmth, closeness and interaction", commercial transactions will not work (Beetles \& Harris, 2010; Granovetter, 1985).

The last indicator is self-control. In other instances, ambiguity in the boundaries of intimacy depends on the prostitute's self-control. This is like a form of self-control practiced by prostitutes in Denmark. Self-control is used as a means to defend oneself by maintaining a professional distance from clients (Järvinen \& Henriksen, 2018). This strategy starts with sexual relations that emphasize more on reciprocity, and will slowly and gradually move towards less frequent sexual services as the number of clients increases. The increase in the number of clients affects the frequency of services that prostitutes have to provide, and ultimately, they will not focus on just one regular client. In a work context, then, the role of intimacy tends to be more complicated and ambiguous, as there needs to be certain boundaries drawn by those who have intimate relationships with their clients and those who do not (Carbonero \& Gómez Garrido, 2018).

\section{Intimacy and Condom Use - Perceptions and Threats}

An increased risk of contracting HIV and other sexually transmitted infections (STIs) can occur through unprotected sex with commercial clients and/or romantic partners. An example is prostitutes in Mexico who tend to use condoms when having sex with their clients but not with their romantic partners. Not using a condom when having sex with their romantic partners is actually for the sake of maintaining intimacy. Therefore, the inconsistent use of condoms when having sex with a client is caused by the intention to maintain intimacy like the way they do it with their romantic partners. However, sometimes the inconsistent use of condoms among prostitutes in Mexico is due to other financial needs that must be met, limited availability of condoms, and lack of access to health services in Mexico (Robertson et al., 2014).

The level of perception between clients and prostitutes appears to be a major threat and a reason for inconsistent use of condom. The frequency of use of condoms among clients (both tourists and locals) and female prostitutes in Indonesia in commercial vaginal sex is still high but not consistent (Ford et al., 1996; Magnani et al., 2010; Putra et al., 2020; Thorpe et al., 1997). The Indonesian prostitutes' inconsistent perception on the use of condoms is caused by two factors, namely knowledge and negotiation skills. Low levels of education correlate with low condom use, resulting in the prostitutes' lack of knowledge. Prostitutes' skills in negotiating with their clients to use condoms are also important because with this effort, prostitutes can prevent HIV-STIs transmission and reject unsafe sex (Putra et al., 2020). The intimacy in the relationship between prostitutes and clients is characterized by a close personal emotional tie which continues to develop from interactions, sexual contact, economic to social support, which are the main factors of the lowered consistency in the use of condoms.

Prostitutes in Indonesia are also reported to have had sexual intercourse without using a condom when a client became close to them beyond the commercial relationship, or even developed a romantic relationship with them (Basuki et al., 2002; Magnani et al., 2010). It is not uncommon to see that prostitutes' boyfriends are the people around them 
such as pimps, or the gatekeepers of commercial sex (Magnani et al., 2010). Clients also assume that they do not need to use a condom when having commercial sex, because if a client uses a condom with a prostitute, it will be no different from having a sexual intercourse with his wife or other girlfriends (Basuki et al., 2002). Indonesian prostitutes in Basuki's study (2002) also emphasized that they would not offer condoms when the client had become their regular client. It is also assumed that using condoms is uncomfortable, feels cold, and makes sexual intercourse not last long (Basuki et al., 2002). It is clear that in this case intimacy has become a significant variable in condom utilization by prostitutes in Indonesia. Condom use is believed to be a sign of intimacy between prostitutes and clients, both sexually and psychologically. Reflecting on this situation, even though not using condoms actually poses a threat of contracting HIV-STIs, it is sexually beneficial for clients and prostitutes.

Similar to the condition in Indonesia, unprotected sex by prostitutes in Mexico also increases as their commercial relationships become more developed emotionally, and Mexican prostitutes even strive to foster long-term relationships by keeping their intimacy with their clients in the hope of earning stronger financial support (Robertson et al., 2014). Research conducted by Carbonero and Gómez Garrido (2018) also mentioned that prostitutes in Spain usually have oral sex without using a condom. Prostitutes who already have long-term clients also say that they do not use condoms consistently with their clients (Bailey \& Figueroa, 2018). This case proves that even though they do oral sex in a commercial context, it may indicate that the sexual pleasure provided is 'authentic and natural. Sanders (in Carbonero \& Gómez Garrido, 2018) said that condoms are important not only because they prevent sexually transmitted diseases and pregnancy, but because condom use will filter out feelings of intimacy in sexual practices.

Warr and Pyett (1999) argued that while women use condoms in commercial sex, they do not use any in their non-commercial sex. The use of condoms in personal relationships is perceived to decrease the ability to feel love or intimacy with a romantic partner during a sexual intercourse. As such, the use of condoms in non-commercial relationships is often identified as lack of trust and love for a partner (Warr \& Pyett, 1999).

Overall, the relationship between sexuality and personal feelings necessitates a strategy from the prostitute to distance herself from sexual relations which also involve personal feelings. The use of condoms with clients in this case is the main strategy that provides a physical barrier in sexual acts, and keeps feelings of intimacy and love away as a survival strategy that is also important for prostitutes (Deering et al., 2011; Warr \& Pyett, 1999). Certain sexual activity, such as kissing, cuddling, or other affectionate behaviors are non-existent in the sexual services offered to clients. At the same time, not using a condom with a romantic partner becomes a symbol of love, trust and intimacy.

On the other hand, Deering et al. (2011) said the opposite. The use of condoms on non-commercial partners will increase two times higher than that on commercial partners. This can happen especially to those who know that their partner is a prostitute. The greater utilization of condoms among prostitutes in South India is also linked to the increased awareness of the risks posed by women working as sex workers and the greater involvement of government programs on HIV-STI prevention designed in the area (Deering et al., 2011). 


\section{Conclusion}

Looking at the definitions and history of prostitution in Indonesia and globally, intimacy in prostitution mainly refers to economic relations, namely social embeddedness. Economically speaking, the positive impact of social embeddedness with clients will make a sexual relationship seem more real without physical or psychological manipulation, which means being able to provide optimal service and keep clients. More often than not, prostitution can also be viewed as a professional activity in economic relations. On the other hand, several studies have found that the concept of social embeddedness may develop into a form of intimacy between prostitutes and clients, for example when a prostitute becomes the client's mistress, which may lead to a special relationship. In this context, several studies have argued that one of the purposes of prostitution still boils down to the economic aspect; namely to sustain financial needs as well as a means to achieve the goals of the prostitute.

Intimacy in prostitution becomes more complex if it lies in between two discourses, namely sexual relation as a form of affection and sexual relation as a form of economic relations. This is even more relevant if the prostitutes are in two different worlds, namely social embeddedness with their clients, and intimacy with their noncommercial partners. Based on the above study, kissing is an expression of intimacy between prostitutes and clients. Learning from studies conducted in foreign countries, there are several indicators on the boundaries of intimacy that can be further studied in cross-cultural research. In addition, condoms are a tool that is often used as a differentiating factor between intimate and non-intimate relationships. Consistent utilization of condoms can be a way of limiting the intimacy between prostitutes and their commercial clients in addition to their being used to prevent HIV-STI transmissions. Meanwhile, not wearing a condom is an expression of the prostitute's loyalty to her partner. Does this expression of loyalty then mean putting our partners in HIV-STI risk groups?

It becomes interesting to further investigate the dynamics and real interpretation of intimacy in prostitution in general; moreover, research on intimacy in prostitution is mostly conducted in the western context, whereas overlooked in Indonesia, which is the shortcoming of this literature study. The previous studies focus more on the economic, legal, religious, and cultural aspects of prostitution, which often ignore the personal aspects and existence of prostitutes. For it will contribute to the psychological aspect, legal protection, and reproductive health in prostitution.

\section{Funding}

The authors received no financial support for the research, authorship, and/or publication of this article.

\section{Acknowledgment}

The authors would like to thank the anonymous reviewers for their insightful suggestions and careful reading of the manuscript. This research was supported by and part of School of Psychology Udayana University Undergraduate Program. 


\section{Authors' Contribution}

The article was written by two collaborating authors. Each author contributed from the stage of preparation of the article to the stage of submission. The first author conceived the theme and draft of the article, supported by the second author who reviewed and supervised the writing process of the article. The two authors then worked in collaboration in understanding, designing, developing and finalizing the writing of this article.

\section{Conflict of Interest}

There is no conflict of interest in the writing of this article. The first author is a student who has an interest in social and psychological studies of prostitution. The second author is an academic in the field of Social, Health and Clinical Psychology. This article was written to improve the ability of the authors in a professional and sustainable manner in contributing to the science of Psychology.

\section{Orcid ID}

I Kadek Wahyu Pujhana https://orcid.org/0000-0001-6968-2036

Made Diah Lestari https://orcid.org/0000-0001-9762-6680

\section{References}

Artosa, O. A. (2018). Pekerja migran dan ekonomi informal ilegal (prostitusi) di wilayah Pasar Kembang, Yogyakarta. Jurnal Pemikiran Sosiologi, 5(1), 21. https://doi.org/10.22146/jps.v5i1.35400

Bailey, A. E., \& Figueroa, J. P. (2018). Agency, lapse in condom use and relationship intimacy among female sex workers in Jamaica. Culture, Health $\mathcal{E}$ Sexuality, 20(5), 531-544. https://doi.org/10.1080/13691058.2017.1360944

Barker, M.-J., Gill, R., \& Harvey, L. (2018). Mediated intimacy: Sex advice in media culture. Sexualities, 21(8), 1337-1345. https://doi.org/10.1177/1363460718781342

Basuki, E., Wolffers, I., Deville, W., Erlaini, N., Luhpuri, D., Hargono, R., Maskuri, N., Suesen, N., \& Beelen, N. van. (2002). Reasons for not using condoms among female sex workers in Indonesia. AIDS Education and Prevention; New York, 14(2), 102-116. http://dx.doi.org/10.1521/aeap.14.2.102.23901

Beetles, A. C., \& Harris, L. C. (2010). The role of intimacy in service relationships: An exploration. The Journal of Services Marketing; Santa Barbara, 24(5), 347-358. http://dx.doi.org/10.1108/08876041011060459

Carbonero, M. A., \& Gómez Garrido, M. (2018). Being like your girlfriend: Authenticity and the shifting borders of intimacy in sex work. Sociology, 52(2), 384-399. https://doi.org/10.1177/0038038516688609

Carey, P., \& Houben, V. (2016). Perempuan-perempuan Perkasa di Jawa Abad XVIII-XIX. Kepustakaan Populer

Gramedia. https://www.goodreads.com/work/best book/49975259-spirited-srikandhis-andsly-sumbadras-the-social-political-and-economi 
Cessia, K. D., \& Lestari, S. B. (2017). Pemahaman pengguna media sosial tinder terhadap fenomena kencan online untuk menjalin hubungan romantis bagi penggunanya. Interaksi Online, 6(1), 10. https://ejournal3.undip.ac.id/index.php/interaksionline/article/view/19116

Czyżowska, D., Gurba, E., Czyżowska, N., Kalus, A., Sitnik-Warchulska, K., \& Izydorczyk, B. (2019). Selected predictors of the sense of intimacy in relationships of young adults. International Journal of Environmental Research and Public Health; Basel, 16(22). http://dx.doi.org/10.3390/ijerph16224447

Deering, K. N., Bhattacharjee, P., Bradley, J., Moses, S. S., Shannon, K., Shaw, S. Y., Washington, R., Lowndes, C. M., Boily, M.-C., Ramesh, B. M., Rajaram, S., Gurav, K., \& Alary, M. (2011). Condom use within non-commercial partnerships of female sex workers in Southern India. BMC Public Health, 11(6), S11. https://doi.org/10.1186/1471-2458-11-S6-S11

Destrianti, F., \& Harnani, Y. (2018). Studi kualitatif pekerja seks komersial (PSK) di daerah Jondul kota Pekanbaru tahun 2016. Jurnal Endurance, 3(2), 302. https://doi.org/10.22216/jen.v3i2.1021

Ford, K., Wirawan, D. N., Fajans, P., Meliawan, P., MacDonald, K., \& Thorpe, L. (1996). Behavioral interventions for reduction of sexually transmitted disease/HIV transmission among female commercial sex workers and clients in Bali, Indonesia. AIDS, 10(2), 213-222. https://doi.org/10.1097/00002030-199602000-00013

Granovetter, M. (1985). Economic action and social structure: The problem of embeddedness. American Journal of Sociology, 91(3), 481-510. https://sociology.stanford.edu/sites/g/files/sbiybj9501/f/publications/economic acti on and social structure.pdf

Henderina, A. (2012). Wanita pekerja seks komersial (Studi tentang patron-client germo dengan PSK di Desa Osango Kecamatan Mamasa Kabupaten Mamasa). Universitas Hasanuddin. http://repository.unhas.ac.id/handle/123456789/2185

Hidayati, N., \& Suhartini, D. E. (2013). Kekerasan pada pekerja seks komersial. Artikel Ilmiah Hasil Penelitian Mahasiswa Universitas Jember (UNEJ), 10.

Hull, T. H., Jones, G. W., \& Sulistyaningsih, E. (1997). Pelacuran di Indonesia: Sejarah dan perkembangannya. Pustaka Sinar Harapan in collaboration with The Ford Foundation.

Jailani, A. S., \& Badriyanto, B. S. (2014). Prostitusi di Jember tahun 1974-2007. Publika Budaya, 2(2), 1-9. http://repository.unej.ac.id/handle/123456789/68097

Järvinen, M., \& Henriksen, T. D. (2018). Controlling intimacy: Sexual scripts among men and women in prostitution. Current Sociology, 001139211881594. https://doi.org/10.1177/0011392118815945

Jeffreys, S. (2008). The Idea of Prostitution. Spinifex Press. 
Khumaerah, N. (2017). Patologi sosial pekerja seks komersial (PSK) perspektif Al-qur an. Junal Al-Khitabah, 3(1), 62-73.

Koentjoro. (2004). On the spot: Tutur dari sarang pelacur. Tinta.

Kusumawati, A., \& Rochaeti, N. (2019). Memutus mata rantai praktik prostitusi di Indonesia melalui kriminalisasi pengguna jasa prostitusi. Jurnal Pembangunan Hukum Indonesia, 1(3), 366. https://doi.org/10.14710/jphi.v1i3.366-378

Liputan6.com. (2014, October 2). Tak "dilayani", ABG di Denpasar bunuh PSK. liputan6.com. https://www.liputan6.com/news/read/2113516/tak-dilayani-abg-di-denpasarbunuh-psk

Magnani, R., Riono, P., Nurhayati, Saputro, E., Mustikawati, D., Anartati, A., Prabawanti, C., Majid, N., \& Morineau, G. (2010). Sexual risk behaviours, HIV and other sexually transmitted infections among female sex workers in Indonesia. Sexually Transmitted Infections; London, 86(5), 393. http://dx.doi.org/10.1136/sti.2009.038059

Matahari, R. (2012). Studi kualitatif mengenai persepsi dan perilaku seksual wanita pekerja seks komersial (PSK) dalam upaya pencegahan IMS di Kota Semarang tahun 2012. Jurnal Kesehatan Reproduksi, 3(3), 113 - 123.

Nazemi, N. (2011). Legalizing prostitution means legitimizing human rights violation! International Journal of Humanities and Social Science, 1(9), 7.

Putra, I. G. N. E., Phuengsamran, D., Jampaklay, A., Thammawijaya, P., \& Januraga, P. P. (2020). Psychological factors associated with protected sex among indirect female sex workers in Denpasar, Bali, Indonesia. AIDS Care, 32(6), 749-757. https://doi.org/10.1080/09540121.2019.1640851

Reis, H. T. (1990). The role of intimacy in interpersonal relations. Journal of Social and Clinical Psychology; New York, 9(1), 15-30. http://dx.doi.org/10.1521/jscp.1990.9.1.15

Ridlwan, M. (2015). Resiliensi berbasis religi bagi mantan PSK dan mucikari pasca penutupan lokalisasi Gandul Tuban. Maraji: Jurnal Ilmu Keislaman, 2(1), 1-23. https://doi.org/10.36835/maraji.v2i1.35

Rivai, H. A. (2012). Fenomena perempuan pekerja seks komersial dengan menggunakan aplikasi chatting internet relay chat mIRC di Yogyakarta (Bachelor's thesis). Faculty of Social Science, Universitas Negeri Yogyakarta.

Rizal, M. (2017). Impression management verbal dan non verbal pekerja seks komersial di Kelurahan Talise. Jurnal Online Kinesik, 4(2), 57-68.

Robertson, A. M., Syvertsen, J. L., Amaro, H., Martinez, G., Rangel, M. G., Patterson, T. L., \& Strathdee, S. A. (2014). Can't buy my love: A typology of female sex workers' commercial relationships in the Mexico-U.S. Border Region. The Journal of Sex Research, 51(6), 711-720. https://doi.org/10.1080/00224499.2012.757283

Rusyidi, B., \& Nurwati, N. (2018). Penanganan pekerja seks komersial di Indonesia. Prosiding Penelitian dan Pengabdian kepada Masyarakat, 5(3), 303-313. https://doi.org/10.24198/jppm.v5i3.20579 
Sumter, S. R., Valkenburg, P. M., \& Peter, J. (2013). Perceptions of love across the lifespan: Differences in passion, intimacy, and commitment. International Journal of Behavioral Development, 37(5), 417-427. https://doi.org/10.1177/0165025413492486

Thorpe, L., Ford, K., Fajans, P., \& Wirawan, D. N. (1997). Correlates of condom use among female prostitutes and tourist clients in Bali, Indonesia. AIDS Care; Abingdon, 9(2), 181-197.

van Anders, S. M., Edelstein, R. S., Wade, R. M., \& Samples-steele, C. R. (2013). Descriptive experiences and sexual vs. Nurturant aspects of cuddling between adult romantic partners. Archives of Sexual Behavior; New York, 42(4), 553-560. http://dx.doi.org/10.1007/s10508-012-0014-8

Vannier, S. A., \& Byers, E. S. (2013). A qualitative study of University students' perceptions of oral sex, intercourse, and intimacy. Archives of Sexual Behavior; New York, 42(8), 1573-1581. http://dx.doi.org/10.1007/s10508-013-0130-0

Vuolajärvi, N. (2019). Precarious intimacies - Europeanised border regime and migrant sex work. Journal of Ethnic and Migration Studies, 45(7), 1090-1107. https://doi.org/10.1080/1369183X.2018.1430558

Wahab, A. J., Kustini, K., \& Ali, M. (2018). Fenomena kawin kontrak dan prostitusi "Dawar" di kawasan Puncak Bogor. ALQALAM, 35(1), 127. https://doi.org/10.32678/alqalam.v35i1.1847

Wahyuni, H. (2014). PSK dan tekanan sosial pasca penutupan Gang Dolly Surabaya. Personifikasi, 5(1), 1-18. https://doi.org/10.21107/personifikasi.v5i1.6567

Warr, D. J., \& Pyett, P. M. (1999). Difficult relations: Sex work, love and intimacy. Sociology of Health $\mathcal{E}$ Illness, 21(3), 290-309. https://doi.org/10.1111/1467-9566.00157 